\title{
A note about spelling
}

In 1842, Mountstuart Elphinstone wrote that "it is always difficult to represent Asiatic words in our own characters, and this is increased in the present instance by want of a uniform system" (p. x). For example, he spelled place names this way: Caubul, Hindoo Coosh and Afghaunistaun. Today there is increasingly common spelling practice, which this book follows, except in direct quotes, where the original has been used. 
Eric James and Tim Jacoby - 9781526123787

Downloaded from manchesterhive.com at 04/26/2023 02: 05 :55PM

via free access 